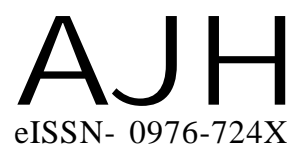

Article history :

Received : 07.05.2014

Revised : 27.10.2014

Accepted : 09.11.2014

Members of the Research Forum

Associated Authors:

${ }^{1}$ Department of Horticulture, N.D.

University of Agriculture and

Technology, Kumarganj, FAIZABAD (U.P.) INDIA

\footnotetext{
Author for correspondence :

H.K. SINGH

Department of Horticulture, N.D.

University of Agriculture and

Technology, Kumarganj, FAIZABAD

(U.P.) INDIA

Email : jitendra_hort@yahoo.com
}

THE ASIAN JOURNAL OF HORTICULTURE

Volume 9 | Issue 2 |Dec., 2014|390-395

Visit us -www.researchjournal.co.in
सA

\section{Integrated nutrient management (INM) on growth, yield and quality of papaya (Carica papaya L.) cv. CO-7}

\section{AMRISH SRIVASTAVA ${ }^{1}$, J.K. SINGH ${ }^{1}$ AND H.K. SINGH}

ABSTRACT : An experiment was conducted during the year 2004-05 and 2005-06 at Main Experiment Station, Department of Horticulture, Narendra Deva University of Agriculture and Technology, Kumarganj, Faizabad (U.P.) to find out the effect of organic manures, inorganic fertilizers and biofertilizers on growth, yield and quality of papaya cv. CO-7. The maximum plant height (201.95 and $201.07 \mathrm{~cm}$ ), circumference $(30.88$ and $32.04 \mathrm{~cm})$ and number of leaves per plant $(32.00$ and 32.16$)$ was recorded with $\mathrm{T}_{10}(\mathrm{FYM}+100 \% \mathrm{NPK}+$ Aztobacter $+\mathrm{PSB})$ which was at par with $\mathrm{T}_{11}(\mathrm{FYM}+$ $100 \% \mathrm{NPK}+$ Azospirillum $+\mathrm{PSB}), \mathrm{T}_{4}$ and $\mathrm{T}_{5}$ and significantly superior as compared to control. However, minimum days to first flower appearence (142.94 and 144.14), height at which first flower appeared $(58.58$ and $58.56 \mathrm{~cm})$ and minimum days of fruit maturity $(159.50$ and 157.41$)$ was recorded in $\mathrm{T}_{10}$ $(\mathrm{FYM}+100 \% \mathrm{NPK}+$ Aztobacter $+\mathrm{PSB})$ closely followed by $\mathrm{T}_{11}(\mathrm{FYM}+100 \% \mathrm{NPK}+$ Azospirillum $+\mathrm{PSB}), \mathrm{T}_{4}$ and $\mathrm{T}_{5}$. The maximum fruit length $(19.75$ and $19.63 \mathrm{~cm})$, width $(13.54$ and $13.75 \mathrm{~cm})$, weight per fruit $(0.950$ and $0.952 \mathrm{~kg}$ ), number of fruit per plant (48.80 and 48.50), yield (46.07 and $48.18 \mathrm{~kg} / \mathrm{plant})$ and shelf life of fruit (7.66 and 8.00 days) was recorded with the application of $\mathrm{T}_{10}$ $(\mathrm{FYM}+100 \% \mathrm{NPK}+$ Aztobacter $+\mathrm{PSB})$ which was at par with $\mathrm{T}_{11}(\mathrm{FYM}+100 \% \mathrm{NPK}+$ Azospirillum $+\mathrm{PSB}), \mathrm{T}_{4}$ and $\mathrm{T}_{5}$ and significantly superior as compared to control. However, chemical composition of fruit viz., maximum TSS (16.78 and $16.80 \%$ ), ascorbic acid (63.77 and $63.73 \mathrm{mg} / 100 \mathrm{~g}$ ), reducing sugars (13.79 and $14.18 \%)$, non reducing sugar (1.62 and 1.66\%), total sugars (15.39 and 15.84\%) and minimum acidity $(0.140$ and $0.139 \%)$ were recorded with $\mathrm{T}_{10}(\mathrm{FYM}+100 \% \mathrm{NPK}+$ Aztobacter + $\mathrm{PSB})$ closely followed by $\mathrm{T}_{11}(\mathrm{FYM}+100 \% \mathrm{NPK}+$ Azospirillum $+\mathrm{PSB}), \mathrm{T}_{4}$ and $\mathrm{T}_{5}$. The maximum net return $\left(\right.$ ha $\left.^{-1}\right)$ was recorded Rs. 471551.25 and Rs. 472801.25 under $\mathrm{T}_{10}(\mathrm{FYM}+100 \% \mathrm{NPK}+$ Aztobacter + PSB $)$ closely followed by $\mathrm{T}_{4}(\mathrm{FYM}+50 \% \mathrm{NPK}+$ Aztobacter + PSB $)$. While, highest net profit per rupee invested (C: B ratio) was noted (1:5.25 and 1:5.29) in $\mathrm{T}_{4}(\mathrm{FYM}+50 \% \mathrm{NPK}+$ Azotobacter + $\mathrm{PSB})$ closely followed by $\mathrm{T}_{5}(\mathrm{FYM}+50 \% \mathrm{NPK}+$ Azospirillum $+\mathrm{PSB}), \mathrm{T}_{10}$ and $\mathrm{T}_{11}$ during both the year. The highest cost: benefit ratio obtained in $\mathrm{T}_{4}$ was due to the higher fruit production and reduced cost of chemical fertilizers as compared to other treatment.

KEY WORDS : INM, Growth, Yield, Quality of papaya

HOW TO CITE THIS ARTICLE : Srivastava, Amrish, Singh, J.K. and Singh, H.K. (2014). Integrated nutrient management (INM) on growth, yield and quality of papaya (Carica papaya L.) cv. CO-7. Asian J. Hort., 9(2) : 390-395. 